\title{
DEVELOPMENT OF A GRANULAR PROCESSING MACHINE
}

\author{
Tayel, S. A. ${ }^{(1)}$, El Nakib, A. A. ${ }^{(2)}$, \\ Yehia, I. ${ }^{(3)}$ EL-ESAILY, M. A. ${ }^{(3)}$
}

\section{ABSTRACT.}

The aim of this study was to develop and testing of granular-processing machine for poultry fodder. The tested parameters were: (1) die speeds of 160, 180, 200, 220, 240 and $260 \mathrm{rpm}$, the die speeds were 80, 90, 100, 110, 120 and $130 \mathrm{rpm}$ (2) hole diameters of 3, 4 and $5 \mathrm{~mm}$ (3) Die thickness of 8,12, 15, 20 and $25 \mathrm{~mm}$. and (4) Moisture content of fodder mixture $5 \%, 10 \%$ and $15 \%$.

The optimum conditions of developed machine were: (1) Die-hole diameter of 3, 4 and $5 \mathrm{~mm}$, (2) Die thickness of $8 \mathrm{~mm}$, (3) Die speed of 220 rpm, (4) Fodder moisture-content of $10 \%$ and (4) Granular dryduration of 69 h. The obtained results in optimum conditions can be summarized as follows: Granular productivity ranged between $185-276$ $\mathrm{kg} / \mathrm{h}$, Granular losses ranged between $3.03-3.78 \%$, real density ranged between $1.1469-1.1491 \mathrm{~g} / \mathrm{cm}^{3}$, Granular durability ranged between 88.9 - 90.7 and Machine power ranged between $8.89-10.05 \mathrm{~kW}$.

The variables affecting the granular productivity, total losses, density were combined into dimensionless groups. The general equations were formulated inside the paper.

The production costs at optimum conditions were 12 to 11.7164 .84 , 54.17 and 43.84 L.E./ton for die-hole diameters 3 and 4 and $5 \mathrm{~mm}$ respectively.

\section{1 - INTRODUCTION.}

7 he shortage in traditional feedstuffs is one of the most important problems challenging the poultry production industry in Egypt.

The cost of feeding constitutes about $60-70 \%$ of total poultry production (El-Derey, 2005). In addition, the feed materials increase continuously and consequently of poultry product prices (meat and eggs).

For this reason, many attempts have been carried

(1) and (2) Prof. of Ag. Eng. Dept., Faculty of Ag., Al-Azhar University.

(3) and (4) Chief Res., and Ass. Res. Ag.. Eng. Res. Inst. 
out to look for alternative the sources such as agricultural residues to overcome this problem.

Awady (1989) mentioned that appropriate mechanization technologies should fulfill the three following parameters: (1) Proper functioning in handling the job for which it is designed, (2) Economical aspects, and (3) Matching with the present technological status while maintaining sustainability and safety requirements. So, various agricultural machines must be designed and manufactured to save time and work, and to protect the environment. The designed machine must not be expensive, simple in construction and operation in all environmental conditions.

Packaging technology of voluminous forage or fodder materials into dense stable units is presently widely spreading throughout the farmworld due to its versatile benefits. This technique prevents segregation of the feed components and facilitates handling and feeding conditions associated with increasing production of animals fed in compact units.

El-Attar (2010) designed, and tested of pelleting machine that produce to feed the cattle and sheep (This machine was developed in this study for granular for poultry feed) used agricultural residues recycling to conserve the environment. The tested factors were: (1) die hole-diameters of 5 (for rabbit), 8, 10 (for cheep) and $12 \mathrm{~mm}$ (for cattle). (2) Die speeds of 100, 180, 250 and $320 \mathrm{rpm}$ (3) Clearnce between die and rollers of 0, 0.5, 1.0 and $1.5 \mathrm{~mm}$. (4) Moisture content of fodder of 5, 10 and $15 \%$. (5) Molasses content of 5,10 and 15. The tested cheep and cattle rations consist of $50 \%$ rice straw (treated by urea), $15 \%$ barseem hay, $10 \%$ wheat bran, 10 soybean meals, and $15 \%$ yellow corn. The maximum machine pellet-productivity of $247 \mathrm{~kg} / \mathrm{h}$ was obtained with die speed of $250 \mathrm{rpm}$, die-hole diameter of $12 \mathrm{~mm}$ and clearance between rollers and die of $0.5 \mathrm{~mm}$. Meanwhile, the minimum machine pellet-productivity of $95 \mathrm{~kg} / \mathrm{h}$ was obtained with die speed of $320 \mathrm{rpm}$, die-hole diameter of 5 $\mathrm{mm}$ and clearance between rollers and die of $1.5 \mathrm{~mm}$. This machine (designed by El-Attar, 2010) was developed in this study to produce granular for poultry. The feed unit was added to this machine to give feed rate acceptable with die-hole diameter. The tested factors to produce granular were: (1) Die-hole diameter ranged between $3-5 \mathrm{~mm}$, (2) Die 
thickness ranged between $8-25 \mathrm{~mm}$, (3) Die speed ranged between 160 - $260 \mathrm{rpm}$, the die speed ranged between 80- $120 \mathrm{rpm}$ and (4) Moisture content of fodder mixture ranged between $5-15 \%$.

The objectives of this study are to develop and test of granular-processing machine for poultry fodder. In addition, some factors affecting the performance and power consumed such as die speed, die-hole diameter, die thickness and fodder moisture-content were studied.

\section{2 - MATERIALS AND METHODS.}

\section{2-1- Materials:}

\section{2-1-1 Designed granular processing-machine:}

The developed granular-machine is shown in Figs. 1 and 2. The machine consists of the following parts:

a) Frame: The frame was made of steel sheet of overall length, width and height of 1010, 705 and $1478 \mathrm{~mm}$ respectively.

(b) Feeding unit: The granular feeding-unit consists of the following parts:

(1) The trapezoidal feeding-hopper was made of steel sheet of $2 \mathrm{~mm}$ thickness, base dimensions of $350 \times 350 \mathrm{~mm}$, top dimensions of $50 \mathrm{x}$ $200 \mathrm{~mm}$ and height of $250 \mathrm{~mm}$.

(2) Feeding chamber consists of a feeding housing with $90 \mathrm{~mm}$ diameter and $5 \mathrm{~mm}$ thickness and an auger of $80 \mathrm{~mm}$ diameter and $300 \mathrm{~mm}$ length. The overall dimensions of feeding unit are shown in Fig. 1.

(c) Granular forming-unit: The granular forming-unit consists of the following parts:

(1) Granular forming-chamber. The granular forming-chamber (fig. 2) consists of four parts as follows:

(a) Agitator housing: made of steel pipe with $200 \mathrm{~mm}$ diameter and 5 $\mathrm{mm}$ thickness this closed from the top. The agitator housing was assembled with the top of upper part of forming unit by 4 bolts with 8 mm diameter.

(b) Agitator: consists of 6 fingers with $20 \mathrm{~mm}$ width, $5 \mathrm{~mm}$ thickness and $50 \mathrm{~mm}$ height which welded on steel pipe with $15 \mathrm{~mm}$ 

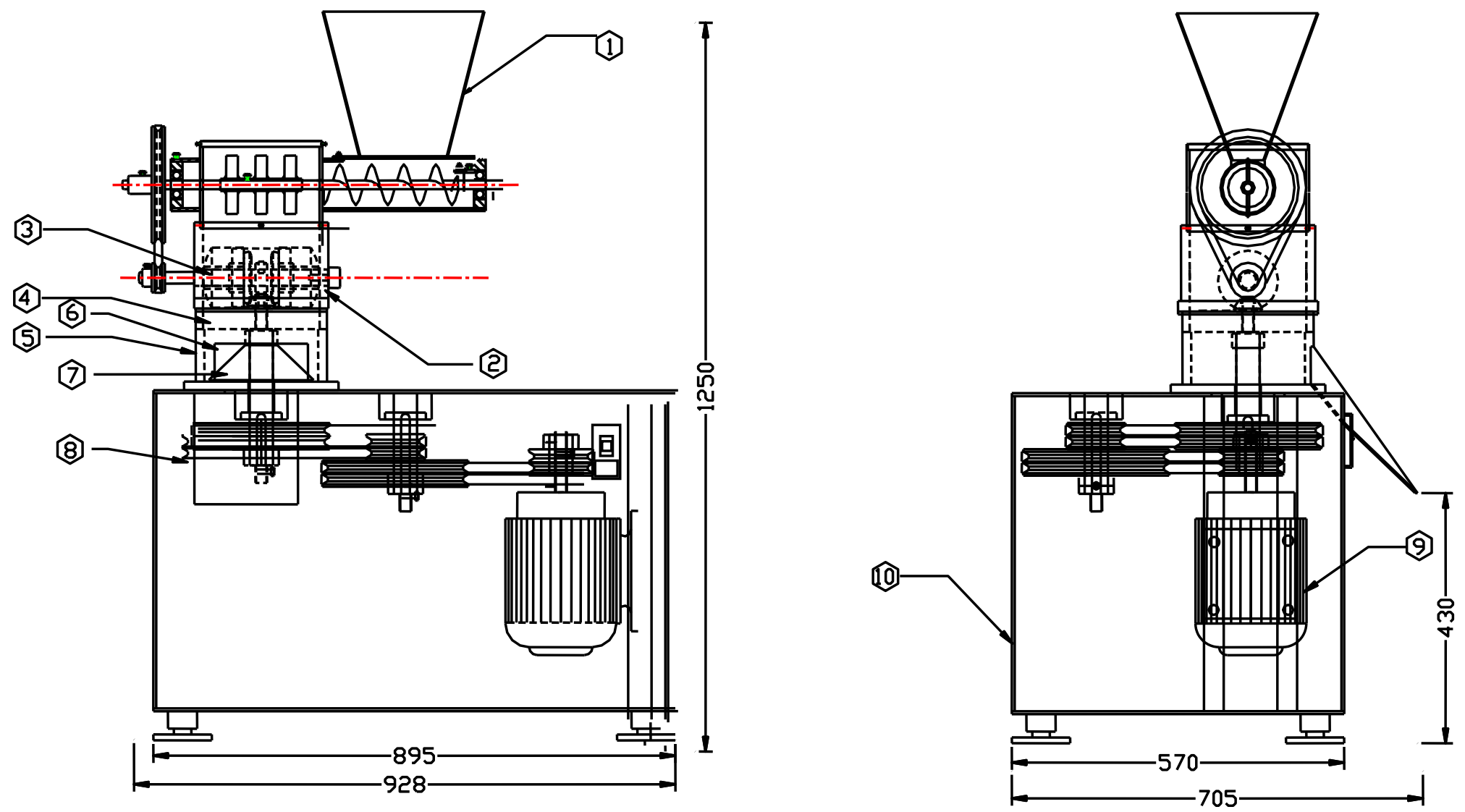

Fig. 1: View of developed granular-machine.

Dim. in $\mathrm{mm}$.

(1) Feeding unit, (2) Pressing chamber, (3) Pressing rollers with bevel gears, (4) Die, (5) Upper part of pressing chamber,

(6) Knife (7) cone, (8) Outlet of granular, (9) Motor, (10) Frame. 


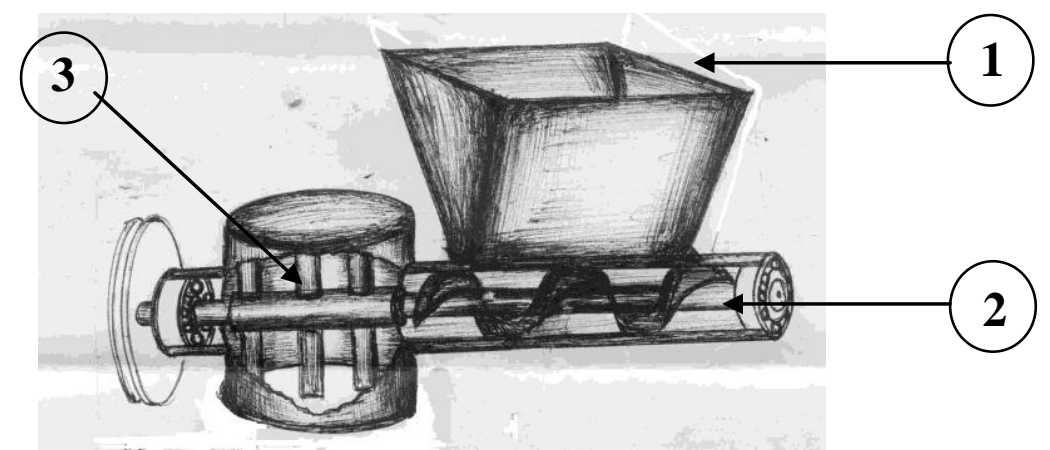

Fig. 2: Assembly of the designed granulating-machine.

(1) Fodder hopper,

(2) Auger,

Agitator, (4) Pressing rollers with bevel gears, (5) Upper part of pressing chamber,

(6) Rollers shaft, (7) Bevel gear of main shaft, (8) Die, (9) Main shaft, (10) Outlet cone, (11) Conical bearing, (12) Lower part of pressing chamber, (13) Outlet of granular, (14) Round bearing, and (15) Pulley of main shaft.

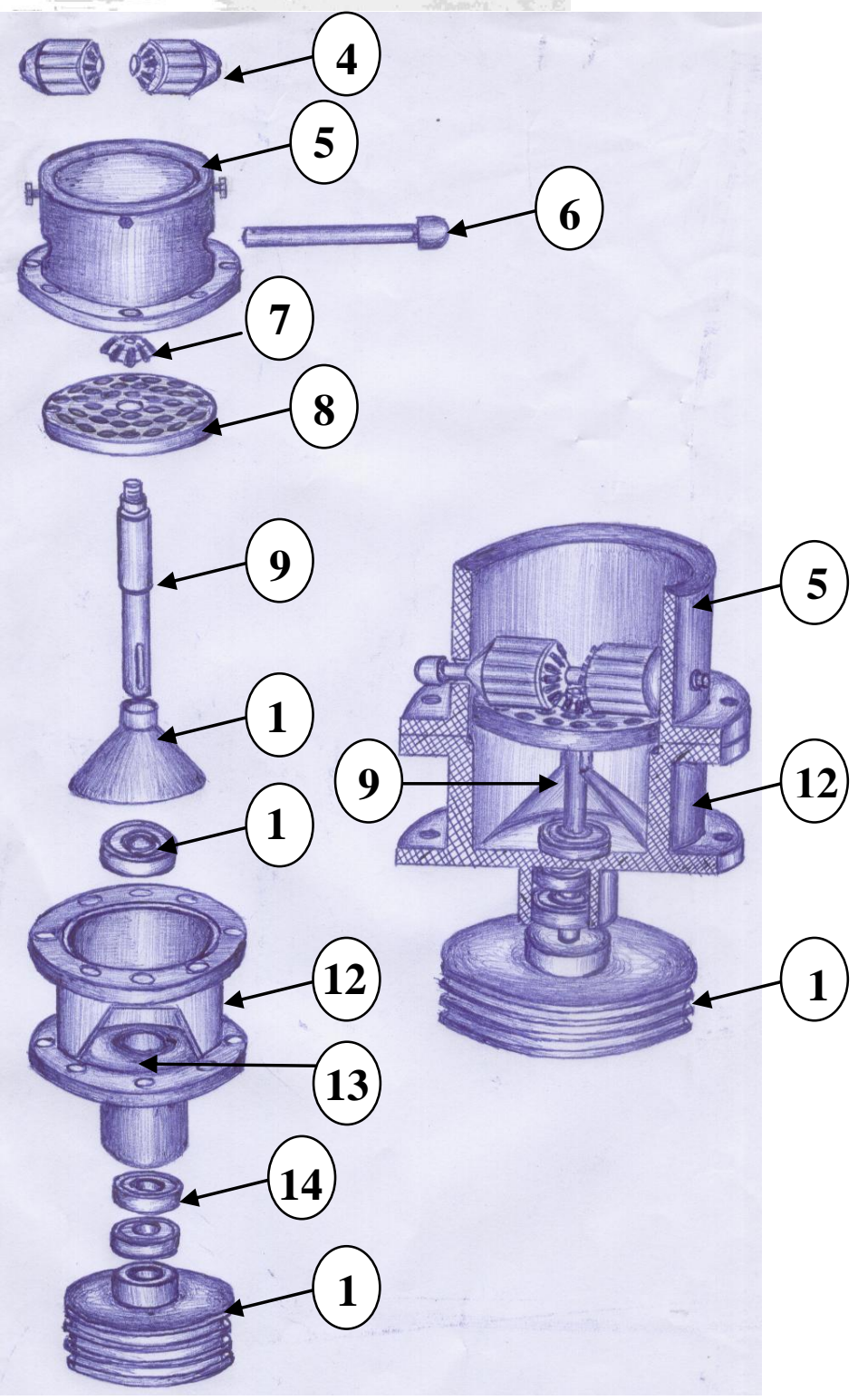


diameter and $200 \mathrm{~mm}$ length. The power is transmitted to agitator from forming rollers by two pulleys and belt. The forming-rollers pulley has $\mathrm{mm}$ diameter and agitator pulley has mm diameter.

(c) The upper part of pressing camper: made of steel pipe with thickness of $20 \mathrm{~mm}$, diameter of $200 \mathrm{~mm}$ and height of $141.5 \mathrm{~mm}$. Two forming rollers are assembled inside the upper part.

(d) The lower part pressing camper: made of steel pipe with the same thickness and diameter of upper part, and $131.5 \mathrm{~mm}$ height. Die was assembled on the top of lower part. And granular cutting-knife and exit cone were assembled under the die.

(2) Forming rollers. The forming rollers were made of steel 37. The two forming-rollers are attached with the upper part of forming chamber by a shaft crossed through the chamber by two holes. The power is transmitted to the forming rollers by main shaft through bevel gears. Every roller made of steel bar with diameter of $103 \mathrm{~mm}$ and length of $70 \mathrm{~mm}$. A copper ring with diameter of $38 \mathrm{~mm}$, length $55 \mathrm{~mm}$ and $5 \mathrm{~mm}$ thickness of $10 \mathrm{~mm}$ was inserted inside every roller. Bevel gear of $90 \mathrm{~mm}$ diameter, total length $38 \mathrm{~mm}$ and number of teeth of 18 was inserted with every roller. The inserted part of bevel gear was $25 \mathrm{~mm}$. The rollers were rotated by a bevel gear with 9 teeth, $50 \mathrm{~mm}$ diameter and $20 \mathrm{~mm}$ width connected to the main shaft as shown in Fig. 2. Clearance between forming rollers and die was $0.2 \mathrm{~mm}$. The clearance was adjusted by putting rings in the bottom of die.

(3) Die: Die was made of alloyed steel plate of $200 \mathrm{~mm}$ diameter and 8, 12, 15, 20 and $25 \mathrm{~mm}$ tested thicknesses. The tested dies were perforated by different hole-diameters of 3, 4 and $5 \mathrm{~mm}$. The die-hole configuration consists of two levels: the first level is a conical shape named "entry" has diameter bigger than straight hole output diameter named "land length". The die geometrical dimensions are shown in table 1 and Figs. 3 and 4.

(4) Knife: Knife was made of spring steel with $3 \mathrm{~mm}$ thickness, $70 \mathrm{~mm}$ width and $170 \mathrm{~mm}$ length. The knife has two slots assembled with the outlet gate by two bolts and nuts at clearance between knife and die bottom $2 \mathrm{~mm}$. The recommended granular length for poultry of $12-22$ weeks age ranged between 2 and $5 \mathrm{~mm}$ Culpin (1986).

Table 1: Die hole-geometry for different tested die-hole diameters. 
FARM MACHINERY AND POWER

\begin{tabular}{|c|c|c|c|c|c|c|c|}
\hline $\begin{array}{c}\text { Die } \\
\text { Thickness, } \\
\text { mm. }\end{array}$ & $\begin{array}{c}\mathrm{d}, \\
\mathrm{mm}\end{array}$ & $\begin{array}{c}\mathrm{L}, \\
\mathrm{mm}\end{array}$ & $\mathrm{L} / \mathrm{d}$ & $\begin{array}{c}\mathrm{D}, \\
\mathrm{mm}\end{array}$ & $\begin{array}{c}\mathrm{I}, \\
\mathrm{mm}\end{array}$ & $\begin{array}{c}\text { No. of } \\
\text { holes }\end{array}$ & $\begin{array}{c}\text { Working } \\
\text { area, } \mathrm{cm}^{2}\end{array}$ \\
\hline \multirow{3}{*}{8} & 3 & 5 & 1.67 & 7 & 3 & 440 & 31.07 \\
\cline { 2 - 8 } & 4 & 5 & 1.25 & 8 & 3 & 264 & 33.16 \\
\cline { 2 - 8 } & 5 & 5 & 1.00 & 9 & 3 & 200 & 39.25 \\
\hline \multirow{3}{*}{12} & 3 & 9 & 3.00 & 7 & 3 & 440 & 31.07 \\
\cline { 2 - 8 } & 4 & 9 & 2.25 & 8 & 3 & 264 & 33.16 \\
\cline { 2 - 8 } & 5 & 9 & 1.80 & 9 & 3 & 200 & 39.25 \\
\hline \multirow{3}{*}{15} & 3 & 12 & 4.00 & 7 & 3 & 440 & 31.07 \\
\cline { 2 - 8 } & 4 & 12 & 3.00 & 8 & 3 & 264 & 33.16 \\
\cline { 2 - 8 } & 5 & 12 & 2.40 & 9 & 3 & 200 & 39.25 \\
\hline \multirow{3}{*}{20} & 3 & 17 & 5.67 & 7 & 3 & 440 & 31.07 \\
\cline { 2 - 8 } & 4 & 17 & 4.25 & 8 & 3 & 264 & 33.16 \\
\cline { 2 - 8 } & 5 & 17 & 3.40 & 9 & 3 & 200 & 39.25 \\
\hline \multirow{3}{*}{25} & 3 & 22 & 7.33 & 7 & 3 & 440 & 31.07 \\
\cline { 2 - 8 } & 4 & 22 & 5.50 & 8 & 3 & 264 & 33.16 \\
\cline { 2 - 8 } & 5 & 22 & 4.40 & 9 & 3 & 200 & 39.25 \\
\hline
\end{tabular}

$\mathrm{d}=$ die hole diameter, $\mathrm{L}=$ land length, $\mathrm{I}=$ cone height and $\mathrm{D}=$ entry diameter.
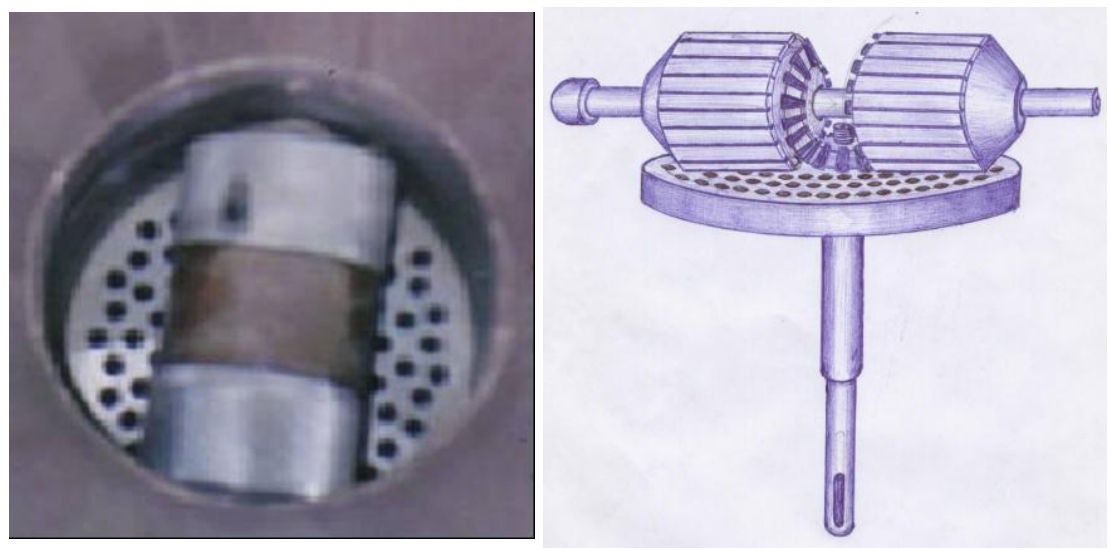

Fig. 3: Sketch and photograph of pressing rollers and die. 


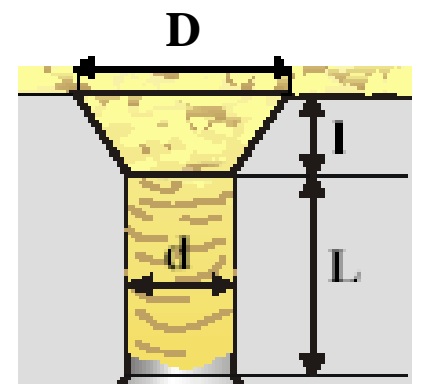

Fig. 4: Die-hole geometry.

(5) The main shaft. The vertical main shaft was made of hard steel 52 carbon. The main shaft has three level diameters of 20,40 and $20 \mathrm{~mm}$ and total length of $295 \mathrm{~mm}$. The main shaft passed through the forming chamber by central hole of $45 \mathrm{~mm}$ diameter in the bottom of body chamber. The main shaft was inserted inside the forming chamber by conical bearing and two round bearings in the bottom of forming chamber as shown in Figs. 1 and 2.

(d) Electrical motor and power transmission: Electric motor of $20 \mathrm{hp}$ $(15.4 \mathrm{~kW})$ and $1350 \mathrm{rpm}$ was sorted on the frame of granular machine. The power was transmitted from the electrical motor by pulleys and vbelts. The tested motor pulley transmits power to double grooves pulley. The diameter of the pulley on the motor shaft was $10 \mathrm{~cm}$. The Pulley of motor shaft transmitted with the pulley with first groove diameter of 25 $\mathrm{cm}$. The second groove with diameter of $10 \mathrm{~cm}$ was connected with the pulley of main shaft (die shaft). The four tested main shaft pulleys with diameters of 20.5, 22.5, 24.5, 27, 30 and $33.5 \mathrm{~cm}$ gave various speeds of the main shaft of 160, 180, 200, 220, 240 and $260 \mathrm{rpm}$ (Fig. 2). The horizontal bevel gear with 9 teeth was connected with the main shaft upper the die. This gear transmitted the power to the forming rollers by connected two 18-teeth bevel gears fixed with two rollers.

\section{2-1-3 Instrumentations:}

\section{(1) Speedometer, stop watch, digital caliper with vernier, digital} balance and graduated cylinder.

A speedometer was used to measure the auger speed and die speed. Stop watch was used for measuring the consumed time for each treatment. Digital caliper with accuracy of $0.01 \mathrm{~mm}$, to measure different dimensions of granular._Digital balance with accuracy of $0.2 \mathrm{~g}$, to measure mass of granular. Graduated cylinder of $1000 \mathrm{ml}$ with accuracy of $25 \mathrm{ml}$ to determine the bulk density and volume of granular. 
(2) Durability tester.: A durability (tumbling box) tester was constructed in Ag. Eng. Res. Inst. according to ASAE standards, 1996. It is fitted with a $23 \mathrm{~cm}$ baffle fixed symmetrically to a diagonal of $30 \mathrm{~cm}$ dimensions box side for tumbling. It is hand rotated about an axis placed inside friction bearings fixed on a stand. A speed indicator at $50 \mathrm{r} / \mathrm{min}$ is connected with the shaft. A $500 \mathrm{~g}$. sieved sample of granular are placed in the box and tumbled for 10min. Durability index is defined as:

Durability $\%=\underline{\text { Intact or undamaged granular mass }} \times 100$

Granular mass before tumbling

\section{2-2 Methods:}

The granular-machine was developed in Production Sector of Agricultural Mechanization in Tookh Station and tested in Agricultural Engineering Research Institute and Animal Production Research Station (Poultry Department) in Gemmiza at years from 2007 and 2010.

2-2-1 Studied factors: Experiments were conducted to study some factors affecting the design and performance of a granular machine. The tested parameters were:

(1) Die speeds: 160, 180, 200, 220, 240 and $260 \mathrm{rpm}$.

(2) Hole diameters: 3, 4 and $5 \mathrm{~mm}$

(3) Die thickness: 8, 12, 15, 20 and $25 \mathrm{~mm}$.

(4) Rollers speeds: 80, 90, 100, 110, 120 and $130 \mathrm{rpm}$.

(5) Moisture content of fodder mixture was 5, 10 and $15 \%$.

\section{2-2-2 Measurements:}

(1) Granular productivity, (2) Total losses of granular, (3) Granular realdensity, (4) Granular durability, and (5) Machine power.

\section{2-2-3 Equations and calculations:}

(1) Granular productivity, $\mathrm{kg} / \mathrm{h}=(\mathrm{Wp} / \mathrm{T}) \times 3.6$

Where: $\mathrm{Wp}=$ granular mass $(\mathrm{g})$ and $\mathrm{T}=$ consumed time $(\mathrm{s})$.

The variables affecting the granular productivity, total losses and density (table 3) were combined into dimensionless groups according to (Khurmi, 1978 and Awady, 1995).

\section{2-1-2 Poultry ration formulations:}

Table 2 shows the components of poultry-finishing diets (12-22 wks of age) ration formulations used in this study. 
The meal was prepared using a hammer mill and mixed in a forage mixture with 5,10 and $15 \%$ of its total mass with water at $50 \mathrm{C}^{\circ}$ and $2 \%$ molasses.

Table 2: The components of poultry-finishing diets (age of 12 - 22 weeks) ration formulations used in this study (El-Derey, 2005).

\begin{tabular}{|c|c|c|}
\hline & Ingredients & $\%$ \\
\hline 1 & Yellow corn & 54.00 \\
\hline 2 & Soybean meal ( $44 \%)$ & 22.94 \\
\hline 3 & Date stone & 12.50 \\
\hline 4 & Dicalcium phosphate & 1.55 \\
\hline 5 & Limestone & 0.80 \\
\hline 6 & $\mathrm{NaC} 1$ & 0.30 \\
\hline 7 & Vit+Min Mix. $^{1}$ & 0.30 \\
\hline 8 & D1-methionine & 0.01 \\
\hline 9 & Washed and dried sand & 7.60 \\
\hline & Total & 100.00 \\
\hline
\end{tabular}

* Vit+Min mixture provides per kilogram of diet.

* Particle size of mixture components is less than about $1 \mathrm{~mm}$.

The resulting dimensionless functional relation is:

$\mathrm{P} /\left(\mathrm{D}_{\text {th }}^{2} \mathrm{~S}_{\mathrm{r}} \rho_{\mathrm{m}}\right)=f\left[\left(\mathrm{D}_{\mathrm{h}} / \mathrm{D}_{\mathrm{th}}\right), \mathrm{M}_{\mathrm{c}},\left(\mathrm{S}_{\mathrm{d}} / \mathrm{S}_{\mathrm{r}}\right)\right]$

$\left.\mathrm{P}=\left(\mathrm{D}_{\text {th }}^{2} \mathrm{~S}_{\mathrm{r}} \rho_{\mathrm{m}}\right) \mathrm{K}_{1}\left(\mathrm{D}_{\mathrm{h}} / \mathrm{D}_{\mathrm{th}}\right)^{\mathrm{K}} \cdot\left(\mathrm{M}_{\mathrm{c}}\right)_{3}^{\mathrm{K}} \cdot\left(\mathrm{S}_{\mathrm{d}} / \mathrm{S}_{\mathrm{r}}\right)^{\mathrm{K}}{ }_{4}\right]$

(2) Total losses $=\left\{\left(\mathrm{W}_{\mathrm{t}}-\mathrm{W}_{\mathrm{P}}\right) / \mathrm{W}_{\mathrm{t}}\right\} \times 100$

Where: $\mathrm{W}_{\mathrm{P}}=$ granular yield mass $(\mathrm{kg})$ and $\mathrm{W}_{\mathrm{t}}=$ sample mass $(\mathrm{kg})$.

The resulting dimensionless functional relation (according table 3 ) is:

$$
\begin{aligned}
& \mathrm{L}_{\mathrm{t}}=f\left(\mathrm{D}_{\mathrm{h}}, \mathrm{D}_{\mathrm{th}}, \mathrm{M}_{\mathrm{c}} \cdot \mathrm{S}_{\mathrm{d}}, \mathrm{S}_{\mathrm{r}}, \rho_{\mathrm{m}}\right) \\
& \mathrm{L}_{\mathrm{t}}=f\left(\mathrm{D}_{\mathrm{h}} / \mathrm{D}_{\mathrm{th}}, \mathrm{S}_{\mathrm{d}} / \mathrm{S}_{\mathrm{r}}, \mathrm{M}_{\mathrm{c}}\right) \\
& \left.\mathrm{L}_{\mathrm{t}}=\mathrm{K}_{1}\left(\mathrm{D}_{\mathrm{h}} / \mathrm{D}_{\mathrm{th}}\right)^{\mathrm{K}}{ }_{2}\left(\mathrm{~S}_{\mathrm{d}} / \mathrm{S}_{\mathrm{r}}\right)^{\mathrm{K}}{ }_{3} \cdot \mathrm{M}_{\mathrm{c}}{ }_{4}\right)
\end{aligned}
$$

(3) Granular real-density $=\left(\mathrm{W}_{\mathrm{d}} / \mathrm{V}_{\mathrm{d}}\right) \times 100$

Where: $\mathrm{W}_{\mathrm{d}}=$ granular mass $(\mathrm{g})$ and $\mathrm{V}_{\mathrm{d}}=$ granular real-volume $\left(\mathrm{cm}^{3}\right)$.

The resulting dimensionless functional relation (according table 3 ) is:

$$
\begin{aligned}
& \rho_{\mathrm{g}}=f\left(\mathrm{D}_{\mathrm{h}}, \mathrm{D}_{\mathrm{th}}, \mathrm{M}_{\mathrm{c}} . \mathrm{S}_{\mathrm{d}}, \mathrm{S}_{\mathrm{r}}, \rho_{\mathrm{m}}\right) \\
& \rho_{\mathrm{g}} / \rho_{\mathrm{m}}=f\left(\mathrm{D}_{\mathrm{h}} / \mathrm{D}_{\mathrm{th}}\right), \mathrm{M}_{\mathrm{c}}\left(\mathrm{S}_{\mathrm{d}} / \mathrm{S}_{\mathrm{r}}\right)
\end{aligned}
$$

Table 3: The variables affecting the granular productivity, total losses and density. 


\begin{tabular}{|c|c|c|c|}
\hline No. & Variables & Symbol & Dimension \\
\hline 1 & Granular productivity. & $\mathrm{P}$ & $\mathrm{M} / \mathrm{T}$ \\
\hline 2 & Density of fodder mixture. & $\rho_{\mathrm{m}}$ & $\mathrm{M} / \mathrm{L}^{3}$ \\
\hline 3 & Density of granular & $\rho_{\mathrm{g}}$ & $\mathrm{M} / \mathrm{L}^{3}$ \\
\hline 4 & Die-hole diameter & $\mathrm{D}_{\mathrm{h}}$ & $\mathrm{L}$ \\
\hline 5 & Die thickness. & $\mathrm{D}_{\mathrm{th}}$ & $\mathrm{L}$ \\
\hline 6 & Die speed. & $\mathrm{S}_{\mathrm{d}}$ & $\mathrm{L} / \mathrm{T}$ \\
\hline 7 & Rollers speed. & $\mathrm{S}_{\mathrm{r}}$ & $\mathrm{L} / \mathrm{T}$ \\
\hline 8 & Moisture content of granular. & $\mathrm{M}_{\mathrm{c}}$ & $\%$ \\
\hline
\end{tabular}

(M, L, T are principals of mass, length, and time resp.)

\section{(4) Estimation of power requirements:}

Total consumed power $(\mathrm{kW})$ under machine working load was estimated by using Wattmeter (700-k type) having an accuracy of $\pm 1 \%$. Then, the power was estimated from the knowledge of line current strength in Amperes (I) and potential difference values. Then the actual power of the machine $(\mathrm{P})$ was then estimated according to (Kurt, 1979) as follow:

$$
\mathrm{P}=\sqrt{3} \text {. I. V. } \eta \text {. } \operatorname{Cos} \Theta / 1000 \quad \mathrm{~kW}
$$

Where:

$\mathrm{I}=$ line current strength in Amperes; $\mathrm{V}=$ potential difference (voltage) being equal to $380 \mathrm{~V}$; $\eta=$ mechanical efficiency (assumed to be $95 \%$ ); $\operatorname{Cos} \Theta=$ power factor (was taken as $85 \%$ ).

Specific energy requirements in $(\mathrm{kWh} / \mathrm{ton})$ were calculated using the following equation:

(6) Estimating the costs of using the machines: Cost of operation was calculated according to the equation given by Awady (1978), in the following form:

$$
\mathrm{C}=\mathrm{p} / \mathrm{h}(1 / \mathrm{a}+\mathrm{i}+\mathrm{t} / 2+\mathrm{r})+(\mathrm{Ec} * \mathrm{Ep})+\mathrm{m} / 144,
$$

Where: $\mathrm{C}=$ hourly cost, $\mathrm{p}=$ price of machine, $\mathrm{h}=$ yearly working hours, $\mathrm{a}$ $=$ life expectancy of the machine, $\mathrm{i}=$ interest rate/year, $\mathrm{t}=$ taxes, $\mathrm{r}=$ overheads and indirect cost ratio, $\mathrm{Ec}=$ Electricity consumption $\mathrm{kW}$, Ep = Electricity price L.E/kW.h, "144" are estimated monthly 
working hours. Notice that all units have to be consistent to result in L.E/h.

Production cost, L.E./ton = Operation cost, L.E./h / Machine productivity, ton/h

\section{RESULTS AND DISCUSSION}

1 Effect of die speed, thickness, hole diameter, and fodder moisturecontent on machine granular-productivity.

Fig. 5 shows the effect of die speed, thickness and hole-diameter, and fodder moisture-content on machine granular-productivity.

The maximum machine granular-productivity of $267 \mathrm{~kg} / \mathrm{h}$ was obtained with die speed of $220 \mathrm{rpm}$, die-hole diameter of $5 \mathrm{~mm}$, die thickness of 8 $\mathrm{mm}$ and fodder moisture-content of $10 \%$. Meanwhile, the minimum machine granular-productivity of $76 \mathrm{~kg} / \mathrm{h}$ was obtained with die speed of $160 \mathrm{rpm}$, die-hole diameter of $3 \mathrm{~mm}$, die thickness of $25 \mathrm{~mm}$ and fodder moisture-content of $5 \%$.

Increasing the productivity of granular by increasing die speed and diehole diameter is due to decreasing the consumed time of granular processing and decreasing the dead area of die respectively. Meanwhile, the decreasing of granular productivity by increasing of die thickness is due increasing the consumed time of granular processing. The decreasing of productivity by increasing fodder moisture-content from 5 to $10 \%$ is due to sliding the fodder-mixture layers between rollers and die

The variables affecting the granular productivity were combined into dimensionless groups. The general equation of the granular productivity was formulated to follow:

$$
\mathrm{P}=\left[\mathrm{D}_{\mathrm{h}}{ }^{1.14} \mathrm{M}_{\mathrm{c}}{ }^{0.06} \mathrm{~S}_{\mathrm{d}}{ }^{7} \rho_{\mathrm{m}}\right] /\left[8103\left(\mathrm{D}_{\mathrm{th}}{ }^{0.4} \cdot \mathrm{S}_{\mathrm{r}}{ }^{6}\right)\right] \quad \mathrm{R}^{2}=0.93 .
$$

Where: $\mathrm{P}=$ Granular productivity,

$D_{h}=$ Die-hole diameter, $m$, (ranged between $\left.0.003-0.003 \mathrm{~m}\right)$,

$\mathrm{M}_{\mathrm{c}}=$ Moisture content of granular, (ranged between 5-15\%).

$\mathrm{S}_{\mathrm{d}}=$ Die speed, $\mathrm{m} / \mathrm{s}$, (ranged between 1.67 and $2.72 \mathrm{~m} / \mathrm{s}$ ), 

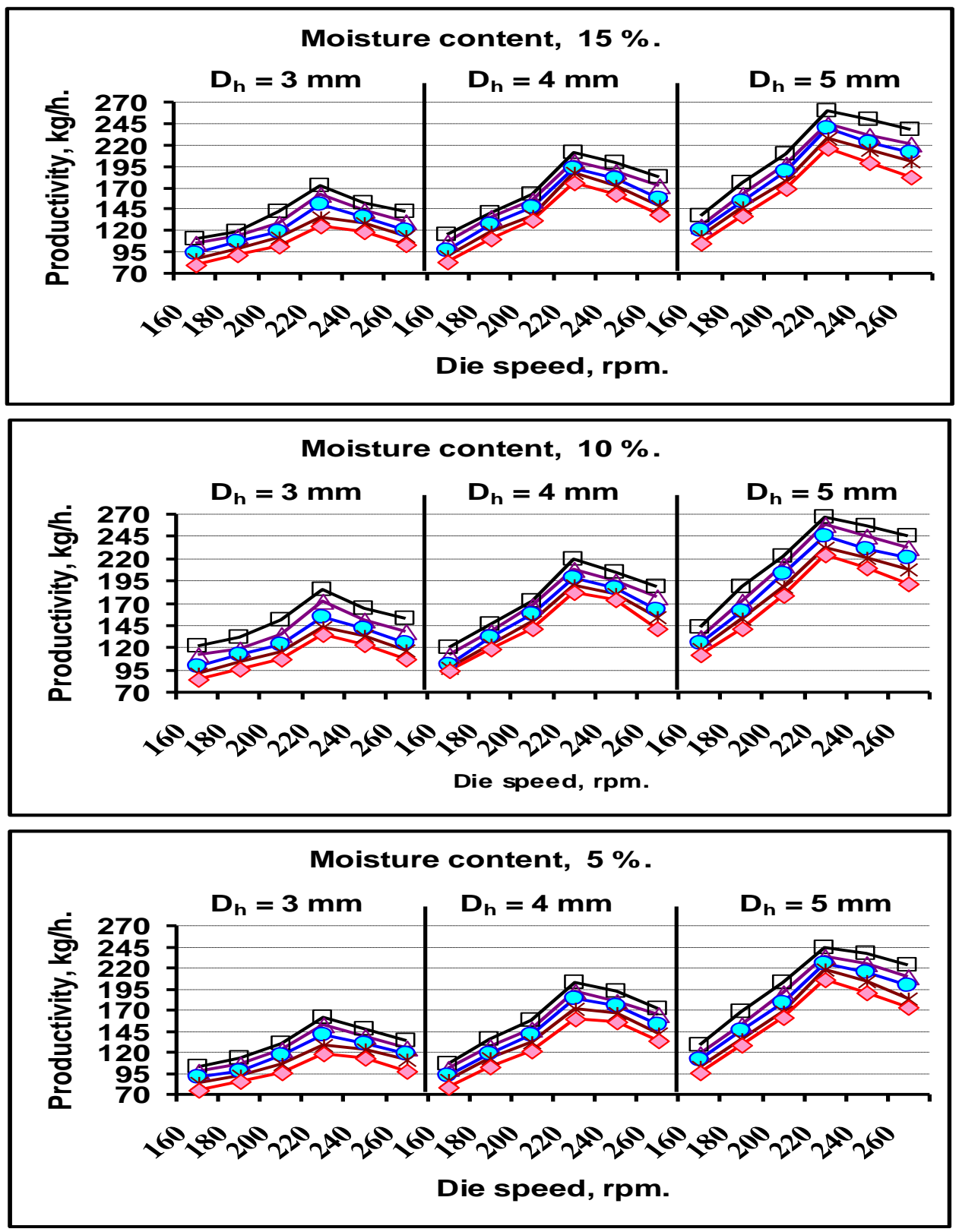

Die thickness

$$
\text { Ð8 } \leftarrow 12-15 \multimap 20 \leadsto 25
$$

Fig. 5: Effect of die speed, thickness, hole diameter, and fodder moisture-content on machine granular-productivity. 


$$
\begin{aligned}
& \rho_{\mathrm{m}}=\text { Density of fodder mixture., } \mathrm{kg} / \mathrm{m}^{3}\left(654 \mathrm{~kg} / \mathrm{m}^{3}\right), \\
& \mathrm{D}_{\mathrm{th}}=\text { Die thickness, } \mathrm{m},(\text { ranged between } 0.008-0.025 \mathrm{~m}) \text { and } \\
& \mathrm{S}_{\mathrm{r}}=\text { Rollers speed, } \mathrm{m} / \mathrm{s} \text {, (ranged between } 0.84 \text { and } 1.36 \mathrm{~m} / \mathrm{s} \text { ). }
\end{aligned}
$$

\section{Effect of die speed, thickness, hole diameter and fodder moisture- content on granular-losses.}

Fig. 6 shows the effect of die speed, thickness and hole-diameter, and fodder moisture-content on machine granular-losses.

The maximum range of granular-losses of $3.56-4.71 \%$ was obtained with die thickness of $8 \mathrm{~mm}$ for all tested die-speeds and diameters. Meanwhile, the minimum range of granular-losses of $2.85-4.03 \%$ was obtained with die thickness of $25 \mathrm{~mm}$ for all tested die-speeds and diameters, anld fodder moisture-contents.

Decreasing the total losses of granular by decreasing die speed and holediameter and by increasing die thickness and fodder moisture-content is due to increasing of compaction of granular particles and stability.

The variables affecting the granular total-losses were combined into dimensionless groups. The general equation of the total losses was formulated to follow:

$\mathrm{L}_{\mathrm{t}}=\left[\mathrm{D}_{\mathrm{h}}{ }^{0.17} \cdot \mathrm{S}_{\mathrm{d}}{ }^{15.4}\right] /\left[8103\left(\mathrm{M}_{\mathrm{c}}{ }^{0.13} \cdot \mathrm{D}_{\mathrm{th}}{ }^{0.17} \cdot \mathrm{S}_{\mathrm{r}}{ }^{15.4}\right)\right] \quad \mathrm{R}^{2}=0.38$.

Where: $\mathrm{L}_{\mathrm{t}}=$ Granular total-losses,

$\mathrm{D}_{\mathrm{h}}=$ Die-hole diameter, $\mathrm{m}$, (ranged between $0.003-0.003 \mathrm{~m}$ ),

$\mathrm{M}_{\mathrm{c}}=$ Moisture content of granular, (ranged between 5-15\%).

$\mathrm{S}_{\mathrm{d}}=$ Die speed, $\mathrm{m} / \mathrm{s}$, (ranged between 1.67 and $2.72 \mathrm{~m} / \mathrm{s}$ ),

$\rho_{\mathrm{m}}=$ Density of fodder mixture., $\mathrm{kg} / \mathrm{m}^{3}$ (ranged between $654 \mathrm{~kg} /$ $\left.\mathrm{m}^{3}\right)$,

$\mathrm{D}_{\mathrm{th}}=$ Die thickness, $\mathrm{m}$, (ranged between $0.008-0.025 \mathrm{~m}$ ) and

$\mathrm{S}_{\mathrm{r}}=$ Rollers speed, $\mathrm{m} / \mathrm{s}$, (ranged between 0.84 and $1.36 \mathrm{~m} / \mathrm{s}$ ).

3 Effect of die speed, thickness, hole diameter and fodder moisturecontent, drying duration on granular real-density.

Fig. 7 shows the effect of die speed, thickness, hole diameter and fodder moisture-content on granular real-density. The granular real-density increased by decreasing die hole-diameter increasing die thickness, fodder moisture-content and die speed from 160 to $220 \mathrm{rpm}$. 

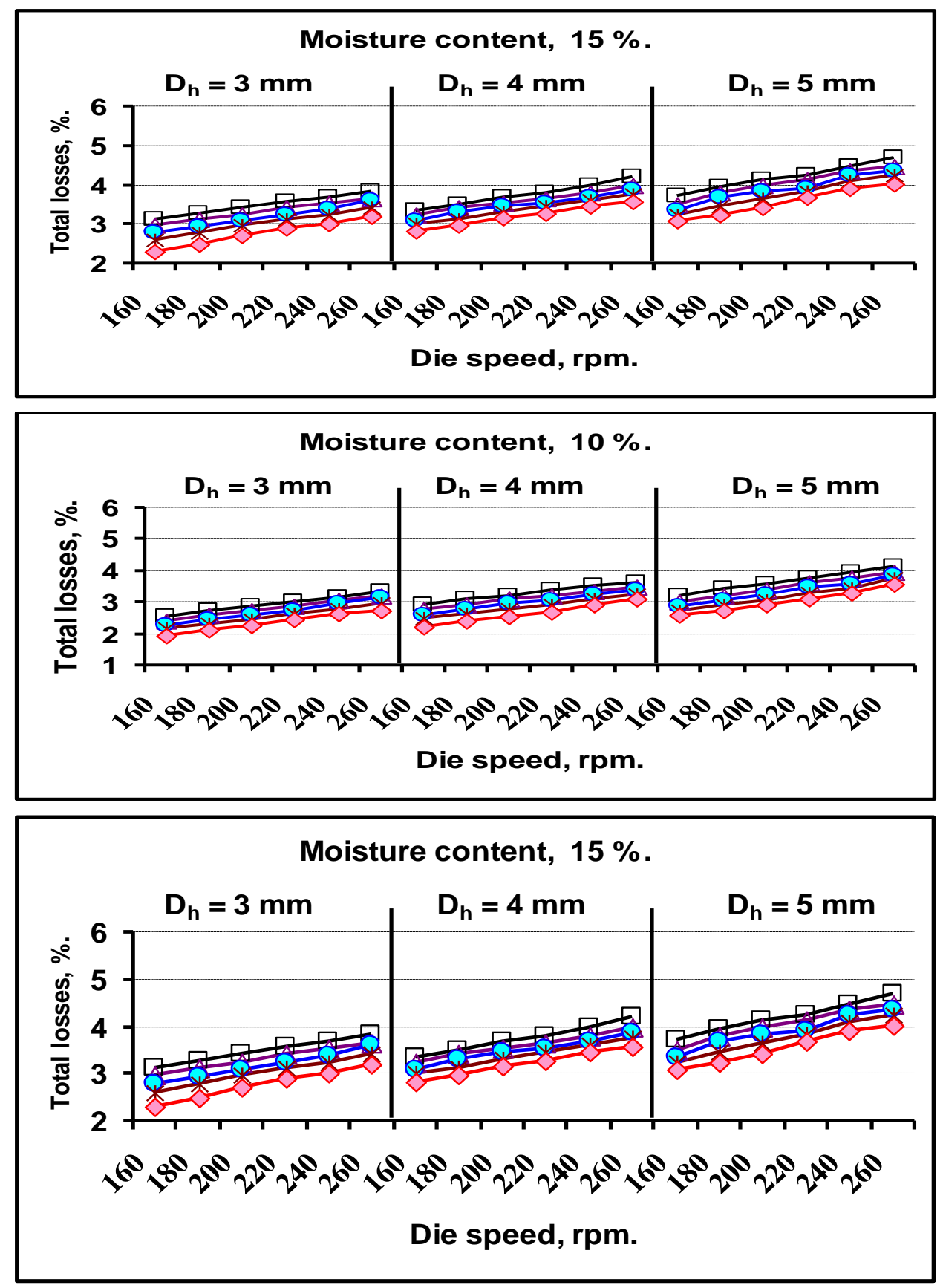

Die thickness

$$
\text { ๑ } 8 \leftarrow 12-0-15 \div 20 \prec-25
$$

Fig. 6: Effect of die speed, thickness, hole diameter and fodder moisturecontent on machine granular-losses. 
The maximum real-density of $1.1634 \mathrm{~g} / \mathrm{cm}^{3}$ was obtained with die speed of $220 \mathrm{rpm}$, die thickness of $25 \mathrm{~mm}$, die hole-diameter of $3 \mathrm{~mm}$, fodder moisture-content of $15 \%$ and drying duration of 96 hours. Meanwhile, the minimum real-density of $1.0983 \mathrm{~g} / \mathrm{cm}^{3}$ was obtained with die speed of $160 \mathrm{rpm}$, die thickness of $8 \mathrm{~mm}$, die hole-diameter of $5 \mathrm{~mm}$, fodder moisture-content of $5 \%$ and drying duration of 96 hours.

The variables affecting the granular density were combined into dimensionless groups. The general equation of the granular density was formulated to follow:

$\rho_{\mathrm{g}}=\left[\rho_{\mathrm{m}} \mathrm{D}_{\mathrm{th}}{ }^{0.009} \cdot \mathrm{M}_{\mathrm{c}}{ }^{0.01} \cdot \mathrm{S}_{\mathrm{d}}{ }^{0.73}\right] /\left[1.107\left(\mathrm{D}_{\mathrm{h}}{ }^{0.009} \cdot \mathrm{S}_{\mathrm{r}}{ }^{0.73}\right)\right] \mathrm{R}^{2}=0.59$.

Where: $\rho_{\mathrm{g}}=$ Granular density,

$\mathrm{D}_{\mathrm{h}}=$ Die-hole diameter, $\mathrm{m}$, (ranged between $0.003-0.003 \mathrm{~m}$ ),

$\mathrm{M}_{\mathrm{c}}=$ Moisture content of granular, (ranged between $5-15 \%$ ).

$\mathrm{S}_{\mathrm{d}}=$ Die speed, $\mathrm{m} / \mathrm{s}$, (ranged between 1.67 and $2.72 \mathrm{~m} / \mathrm{s}$ ),

$\rho_{\mathrm{m}}=$ Density of fodder mixture., $\mathrm{kg} / \mathrm{m}^{3}\left(654 \mathrm{~kg} / \mathrm{m}^{3}\right)$,

$\mathrm{S}_{\mathrm{r}}=$ Rollers speed, $\mathrm{m} / \mathrm{s}$, (ranged between 0.84 and $1.36 \mathrm{~m} / \mathrm{s}$ ).

\section{Effect of die speed, thickness, hole diameter, and fodder moisture-} content on granular durability.

Fig. 8 shows the effect of die speed, thickness and hole diameter, and fodder moisture-content on granular durability. The durability increased by decreasing die speed and hole-diameter, and increased by die thickness and fodder moisture-content.

The maximum durability of $96.3 \%$ was obtained with die speed of 160 rpm, die thickness of $25 \mathrm{~mm}$, die hole-diameter of $3 \mathrm{~mm}$ and fodder moisture-content of $10 \%$. Meanwhile, the minimum durability of $86.7 \%$ was obtained with die speed of $260 \mathrm{rpm}$, die thickness of $8 \mathrm{~mm}$, die holediameter of $5 \mathrm{~mm}$ and fodder moisture-content of $5 \%$.

Increasing granular durability by decreasing die speed and hole-diameter and by increasing die thickness and fodder moisture-content is due to increasing of compaction of granular particles and stability.

\section{Effect of die speed, thickness, hole diameter, and fodder moisture- content on machine power.}

Fig. 9 shows the effect of die speed, thickness and hole diameter, and fodder moisture - content on machine power. The machine power increased by 
Moisture content, $10 \%$.

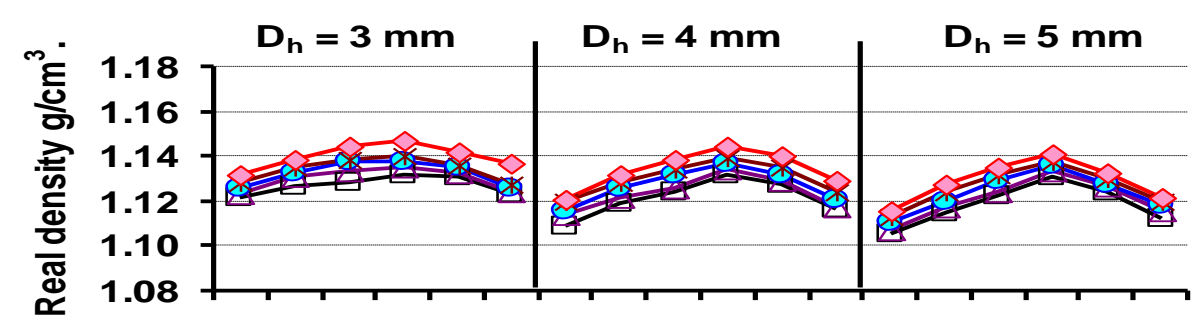

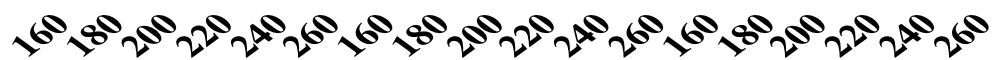

Die speed, rpm.

Moisture content, $15 \%$.

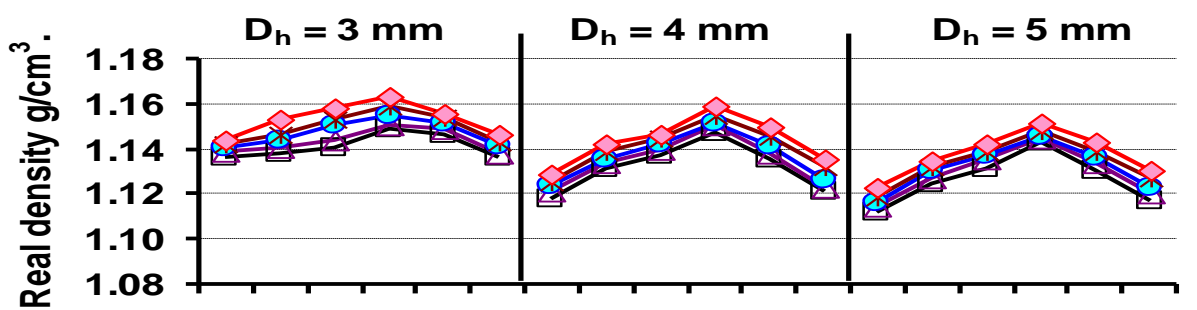

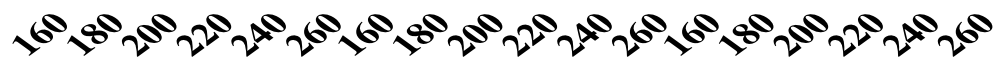

Die speed, rpm.

Moisture content, $5 \%$.

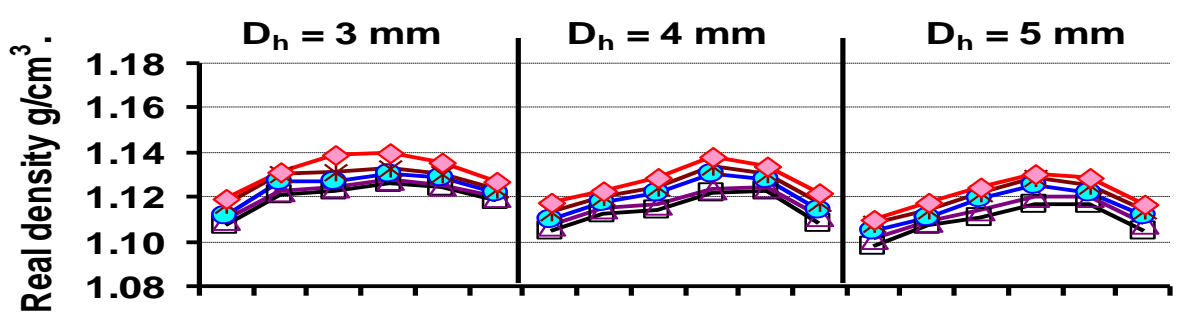

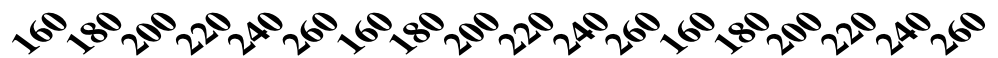

Die speed, rpm.

Die thickness

$$
\square-8 \leftarrow 12-\infty-15 \rightarrow 20 \curvearrowright 25
$$

Fig. 7: Effect of die speed, thickness, hole diameter and fodder moisturecontent on granular real-density. 
increasing die speed, thickness and decreasing die hole-diameter and fodder moisture-content.

The maximum machine power of $12.32 \mathrm{~kW}$ was obtained with die speed of $260 \mathrm{rpm}$, die thickness of $25 \mathrm{~mm}$, die hole-diameter of $3 \mathrm{~mm}$ and fodder moisture-content of $5 \%$. Meanwhile, the minimum granularstiffness of $7.61 \mathrm{~kW}$ was obtained with die speed of $160 \mathrm{rpm}$, die thickness of $8 \mathrm{~mm}$, die hole-diameter of $5 \mathrm{~mm}$ and fodder moisturecontent of $15 \%$.

Increasing machine power by decreasing hole-diameter and fodder moisture-content and increasing die thickness is due to increasing friction between granular and die hole-walls

\section{Cost of using the designed granular processing-machine.}

Tables 4 and 5 show the components of the Awady equation and operation and production costs of using the designed granular processingmachine.

Table 4: The components of Awady equation.

\begin{tabular}{|c|c|c|c|c|c|c|c|c|}
\hline $\begin{array}{c}\mathrm{p}, \\
\text { L.E. }\end{array}$ & $h, h$ & $\begin{array}{c}\mathrm{a}, \\
\text { year }\end{array}$ & $\mathrm{i}$ & $\mathrm{t}$ & $r$ & Ec, kW.h/h & $\begin{array}{l}\text { Ep, } \\
\text { L.E. }\end{array}$ & $\begin{array}{l}\mathrm{m}, \\
\mathrm{L.E}\end{array}$ \\
\hline 10000 & 2000 & 10 & 0.075 & 0.05 & 0.03 & $\begin{array}{l}7.61- \\
12.32\end{array}$ & 0.25 & 1200 \\
\hline \multicolumn{9}{|c|}{$\begin{array}{l}\mathrm{C}=10000 / 2000\{(1 / 10)+0.075+(0.05 / 2)+0.03\}+(10.05 * \\
\quad 0.25)+(1200 / 144)\end{array}$} \\
\hline \multicolumn{9}{|c|}{$=0.075+(0.05 / 2)+0.03\}+(7.92 * 0.25)+(1200 / 144)$} \\
\hline & $11.46 \mathrm{I}$ & $\mathrm{E} . / \mathrm{h}$ fo & die hol & -diam & tor of & $3 \mathrm{~mm}$ & & \\
\hline
\end{tabular}

The operation and production costs were 12, 11.86 and 11.71 L.E./h and 64.84, 54.17 and 43.84 L.E./ton for die-hole diameters of 3, 4 and $5 \mathrm{~mm}$ respectively at optimum condition (die speed of $220 \mathrm{rpm}$, die thickness of $8 \mathrm{~mm}$ and fodder moisture-content of $10 \%$ ).

Table 5: Operation and production costs of different die hole diameters at optimum condition (die speed of $220 \mathrm{rpm}$, die thickness of 8 $\mathrm{mm}$ and fodder moisture-content of $10 \%$ ).

\begin{tabular}{|c|c|c|c|c|}
\hline $\begin{array}{c}\text { Die hole, } \\
\mathrm{mm}\end{array}$ & $\begin{array}{c}\text { Power, } \\
\mathrm{kW}\end{array}$ & $\begin{array}{c}\text { Operation } \\
\text { cost, L.E./h }\end{array}$ & $\begin{array}{c}\text { Machine } \\
\text { productivity, } \\
\text { ton/h }\end{array}$ & $\begin{array}{c}\text { Production } \\
\text { cost, L.E./ton }\end{array}$ \\
\hline 3 & 10.05 & 12.00 & 0.185 & 64.84 \\
\hline 4 & 9.52 & 11.86 & 0.219 & 54.17 \\
\hline 5 & 8.89 & 11.71 & 0.267 & 43.84 \\
\hline
\end{tabular}


Moisture content, $5 \%$.

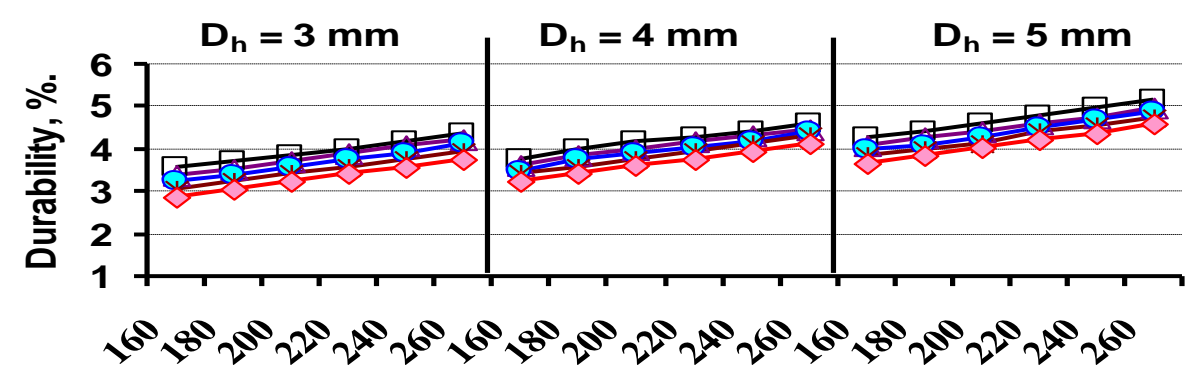

Die speed, rpm.

Moisture content, $15 \%$.

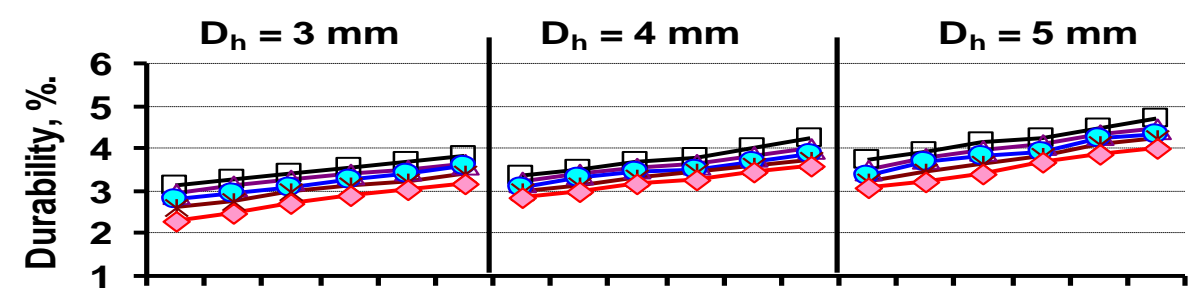

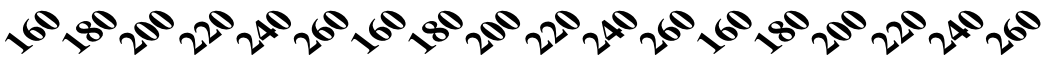

Die speed, rpm.

Moisture content, $10 \%$.

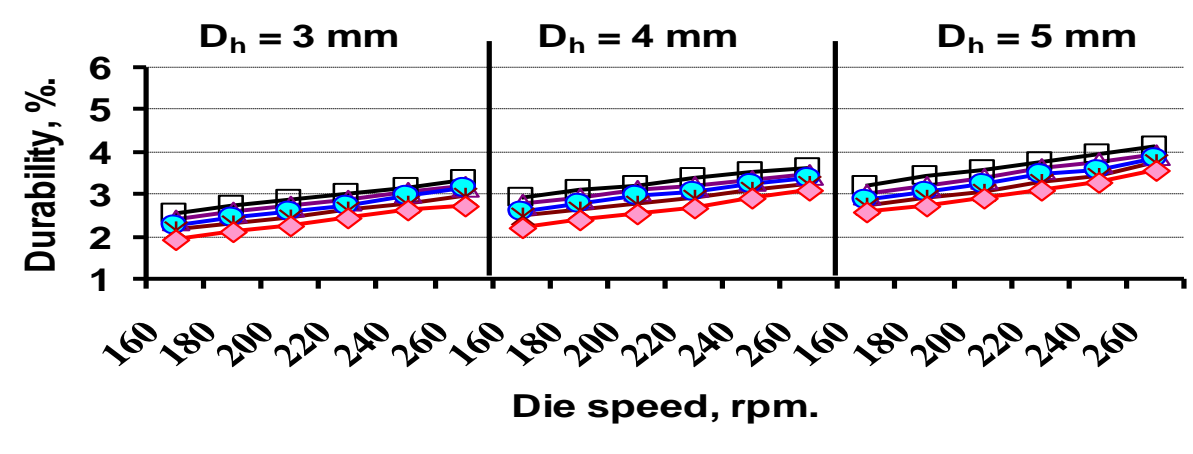

Die thickness

$$
\text { ๑ } 8 \leftarrow 12-15 \leftarrow 20 \prec-25
$$

Fig. 8: Effect of die speed, thickness, hole diameter and fodder moisturecontent on granular durability. 
Moisture content, $10 \%$.

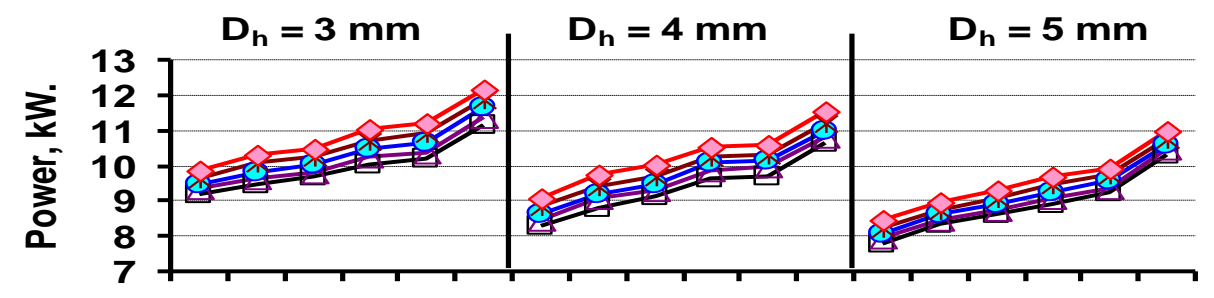

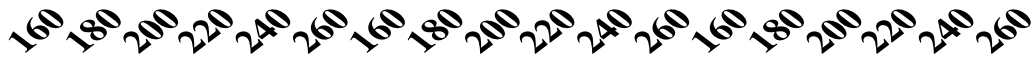

Die speed, rpm.

Moisture content, $5 \%$.

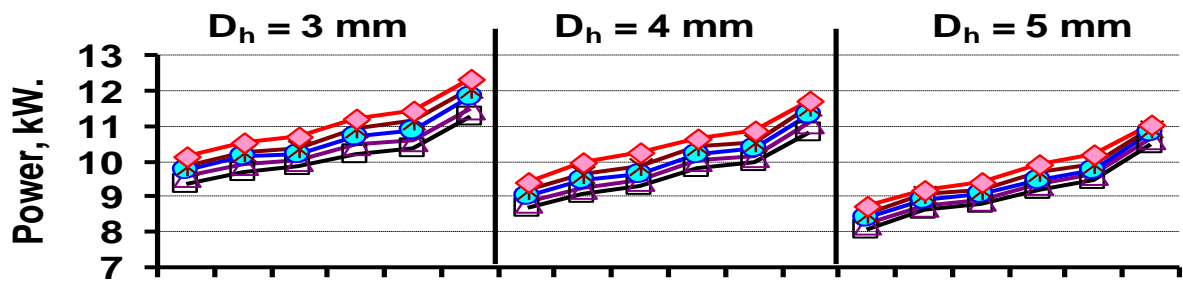

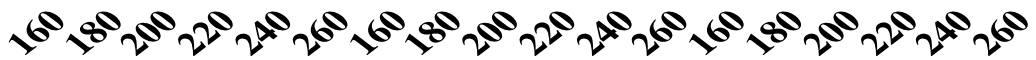

Die speed, rpm.

Moisture content, $15 \%$.

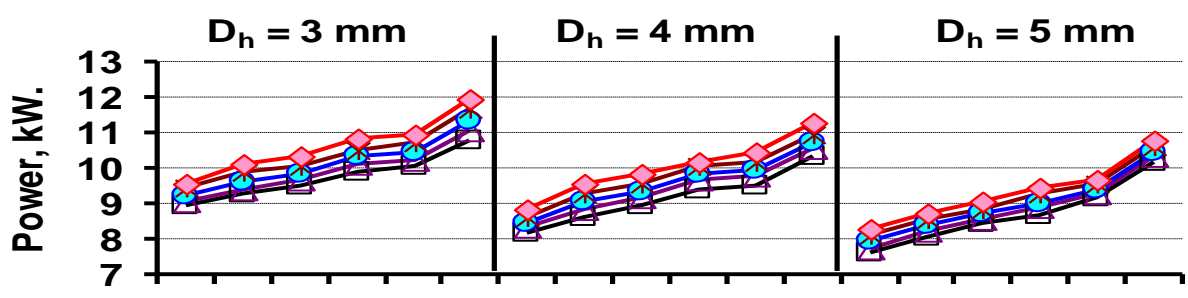

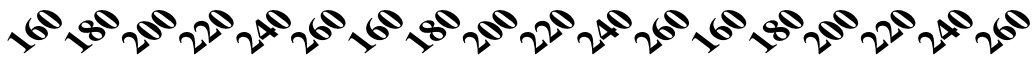

Die speed, rpm.

Die thickness

$$
\leftarrow 8 \leftarrow 12 \multimap-15 \rightarrow 20 \multimap-25
$$

Fig. 9: Effect of die speed, thickness, hole diameter, and fodder moisture-content on machine power. 


\section{SUMMARY AND CONCLUSION}

The optimum conditions of developed machine were: (1) Die-hole diameter of 3, 4 and $5 \mathrm{~mm}$, (2) Die thickness of $8 \mathrm{~mm}$, (3) Die speed of $220 \mathrm{rpm}$, (4) Fodder moisture-content of $10 \%$ and (4) Granular dryduration of $69 \mathrm{~h}$. The obtained results in optimum conditions can be summarized as follows: Granular productivity ranged between 185 - 276 $\mathrm{kg} / \mathrm{h}$, Granular losses ranged between $3.03-3.78 \%$, real density ranged between $1.1469-1.1491 \mathrm{~g} / \mathrm{cm}^{3}$, Granular durability ranged between 88.9 - 90.7 and Machine power ranged between $8.89-10.05 \mathrm{~kW}$.

The operation and production costs ranged between 12 to 11.71 L.E./h and 64.84 to 43.84 L.E./ton for die-hole diameters ranged between 3 and 5

\section{REFERENCES}

ASAE Standards, 1996. Cubes, pellets, and crumbles definitions and methods for determining density, durability, and moisture content: 477-479, 499.

Awady, M. N., 1978, Engineering of tractors and agricultural machinery, Text Bk., col. Ag., Ain-shams U., 5 th Ed. : 164-167. ( In Arabic. ) ( Updating 1998 ).

Awady, M.N., 1989, Appropriate agricultural mechanization in ARE, Egyptian-German Ag. Mec. Conf., Mansura U.: 11-22.

Awady, M. N., 1995, Computer and data analysis, Text memos, Col. Ag., Ain Shams U.: $30-35$.

Culpin, C., 1986, Farm machinery, 11th ed. Granada Pub. Ltd. London ELBS Collins: 276 - 285.

El-Derey, A. A., 2005, Studies on poultry husbandry and nutrition, Ph. D., Animal Production Dept., Mansoura U.: 1-2.

El Attar, A. A., 2010, Design and testing of a pelleting machine for recycling agricultural residues of animal feed, Ph. D., Inst. Environ. Studies and Res., Ain Shams U.: 42-57.

Ibrahim, M. K., 1982, Wet milling grain, M. Sc. Th., Fac. of Ag., Mansoura U.: 61-64.

Khurmi, R. S., 1978, A text book of hydraulics and fluid mechanics, Chand and Co. LTD, New Delhi: 787 - 807. 


\section{تطوير آلة لتصنيع المصني المحبياث

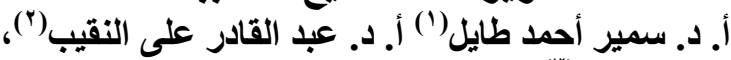

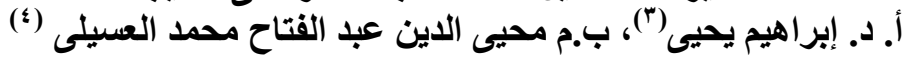

يهدف البحث إلى تطوير واختبار آلة لتصنيع محببات علف الدو اجن. وفكرة عمل الآلة هـى نزول خليط

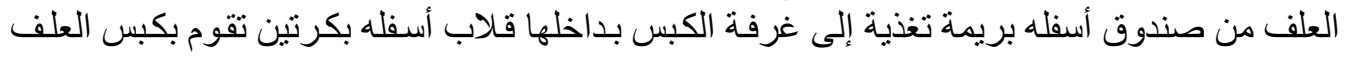

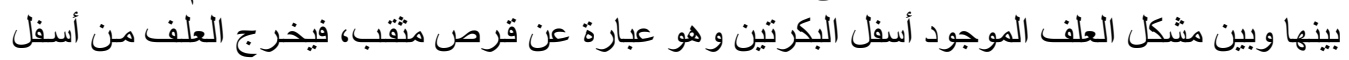

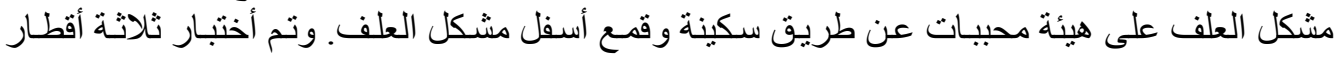

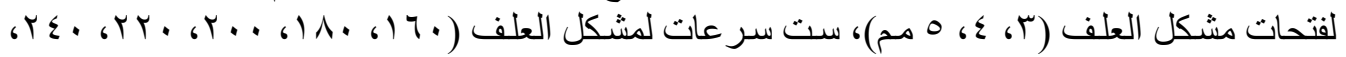

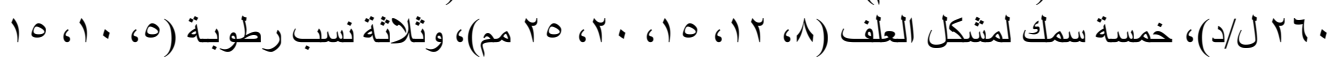
\%). وتم الحصول على النتائج التالية:

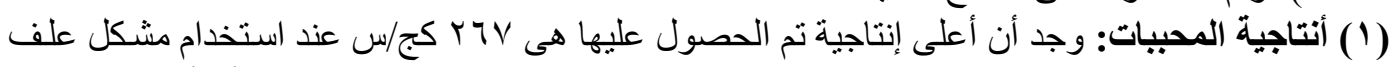

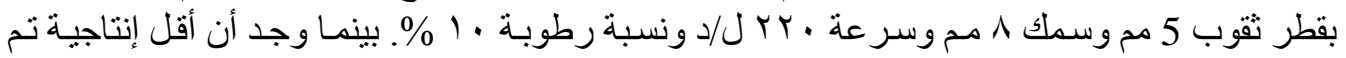

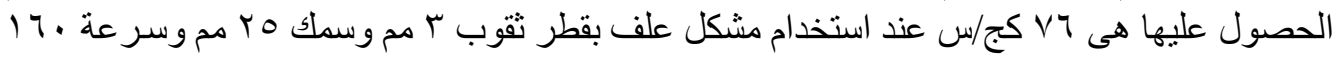

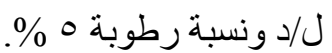

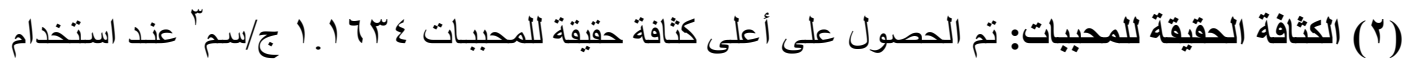

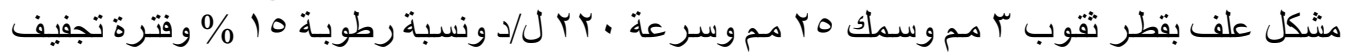

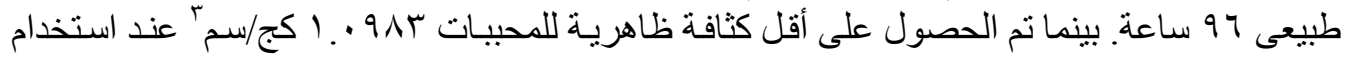

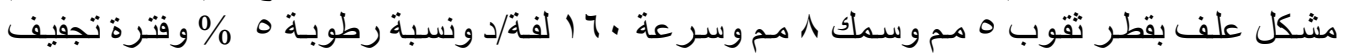
طبيعى 97 ساعة.

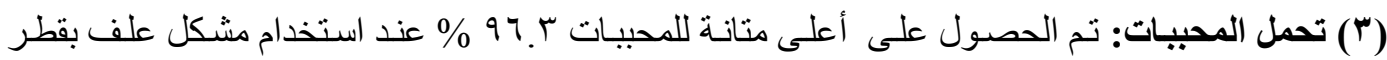

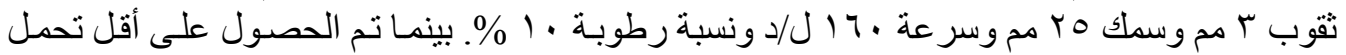

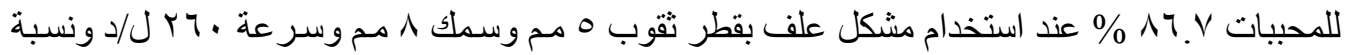
رطوبة ه \% و وذللك باستخدام العلف بعد فترة تجفيف طبيعى 97 و 9 ساعة.

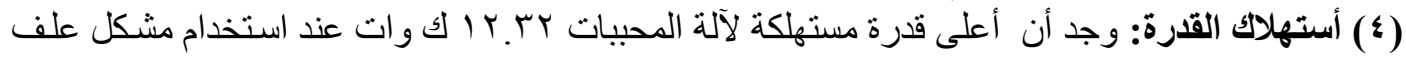

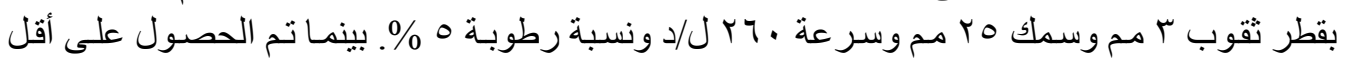

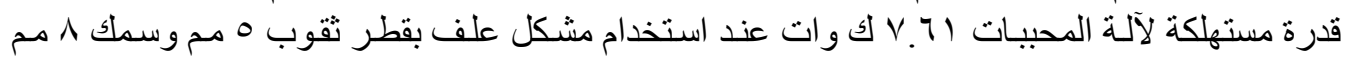

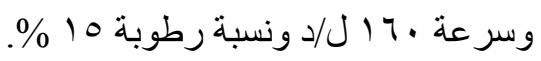

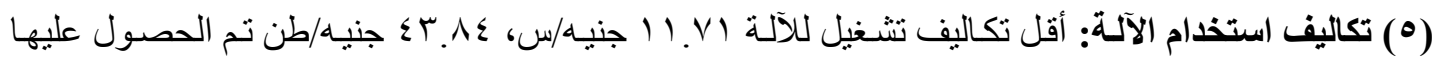

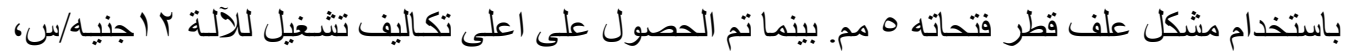

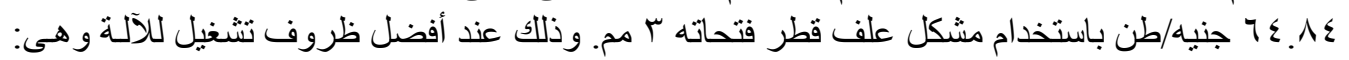

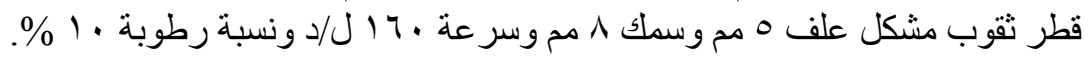

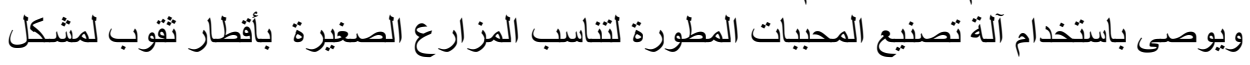

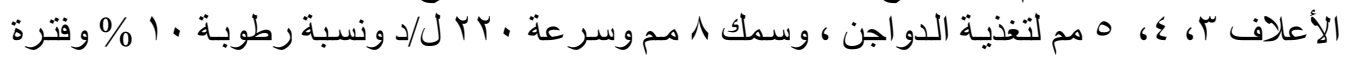
تجفيف 97 س. 